\title{
The Role Of An Supervisors And Supervisory Against Education System Of Education
}

\author{
Henry M. Sopacua*, SEM Nirahua** \\ Graduate Student PhD, Study Program : Science Of Law. Pattimura University, Ambon, Indonesia \\ Faculty Of Law. Pattimura University, Ambon, Indonesia \\ DOI: 10.29322/IJSRP.11.07.2021.p11591 \\ http://dx.doi.org/10.29322/IJSRP.11.07.2021.p11591
}

\begin{abstract}
This study aims to find out, analyze and find out the nature of state supervision on the implementation of the national education system. This study uses a normative legal research method. This research was conducted by examining the concepts, doctrines, theories and provisions of existing legislation using a philosophical approach (Philosophy Approach), a statutory approach ( Statute Approach) and a conceptual approach (conceptual Approach). The results of the study indicate that the implementation of the education system in the regions, especially in Maluku Province, almost all districts/cities in Maluku Province do not have Regional Regulations and/or Regent/Mayor Regulations that specifically regulate the education system in the regions that can run consistently and continuously throughout the period. governance in a sustainable manner. That the reality on the ground proves that the supervisory function in the context of organizing the education system in the regions, especially in the Maluku Province, has stagnated or does not work at all in accordance with the principles of administering a national education system based on Pancasila, the 1945 Constitution of the Republic of Indonesia and the National Education System Law. The management of supervision of the national education system is basically something that is very essential in the life of the organization to ensure that the activities carried out do not deviate from the predetermined plan. With supervision, the advantages and disadvantages in the implementation of management will be known, from the beginning, during the process, and at the end of the management implementation.
\end{abstract}

Keywords: supervisory management, education

\section{INTRODUCTION}

Law No. 20 of 2003 concerning the National Education System states that the purpose of National Education is to develop the potential of students to become human beings who believe and fear God Almighty, have noble character, are healthy, knowledgeable, capable, creative, independent, and become democratic and responsible citizens. Efforts that can be made to realize the goals of National Education as stated in the Preamble to the 1945 Constitution and Law No. 20 of 2003 concerning the National Education System are to improve the quality of national education.

The same thing is also stated in Article 28C of the 1945 Constitution of the Republic of Indonesia, which states that;

1. "Everyone has the right to develop themselves through the fulfillment of their basic needs, the right to education that benefits from science and technology, art and culture, in order to improve the quality of their lives and for the welfare of mankind."

2. "Everyone has the right to advance himself in fighting for his rights collectively to build his community, nation and country."

Based on the two paragraphs contained in the 1945 Constitution of the Republic of Indonesia, that everyone as a citizen has the right to obtain a proper education and provide benefits for himself and has the right to advance himself in order to have a better quality of life in the future. This right is a right that must be respected and upheld by all people and their country.

In addition, the functions and objectives of education are also regulated in Article 3 of the Law of the Republic of Indonesia No. 20 of 2003 concerning the National Education System, which states that; "National education functions to develop capabilities and shape the character and civilization of a dignified nation in the context of educating the nation's life, aiming to develop the potential of students to become human beings who believe and are devoted to God Almighty, have noble character, are healthy, knowledgeable, capable, creative, independent and become a democratic and responsible citizen".

Reviewing the provisions of Article 3 of the Law of the Republic of Indonesia on the National Education System above, in fact the provisions of education in the Law have the function of developing knowledge to educate the nation's life and aiming for all Indonesian people to obtain a proper education. On the basis of the national objectives that have been written in the Law of the Republic of Indonesia on the National Education System no. 20 of 2003, every unit or organization engaged in national education. (Sukardjo and Komarudin, 2013).

The government as the provider of education for the community is expected to provide the best service so that the right to education is obtained properly, Article 4 of the Law of the Republic of Indonesia No. 20 of 2003 concerning the National Education System, states: 
1. "Education that is held in a democratic and fair manner and is not discriminatory by upholding human rights, religious values, cultural values and national pluralism".

2. "Education is organized as a systemic unit with an open and multi-meaning system".

3. "Education is held as a process of cultivating and empowering learners that lasts a lifetime".

4. "Education is held by setting an example, building the will, and developing the creativity of students in the learning process".

5. "Education organized by developing a culture of reading, writing, and arithmetic for all citizens".

6. "Education organized by empowering all components of society through participation in the implementation and quality control of education services".

Based on the six paragraphs contained in the Law of the Republic of Indonesia No. 20 of 2003 concerning National Education, that the principle of education is carried out democratically and upholds human rights, religious values, systematically, lasts a lifetime, provides an example, develops a reading culture, and as a participation in the implementation and control of service quality education.

Based on theoretical studies and national education policies, there is really no doubt that school supervisors are an important part of the national education system. Nana Sudjana, stated:(Sukardjo and Komarudin, 2013) "Superintendents of TK/SD, SMP, SMA and SMK are educational staff whose role is very important in fostering the professional ability of educators and principals in improving school performance". However, in its implementation in the field, educational supervision activities by school supervisors seem to be far from what is expected. In the field, there are still many problems that surround educational supervision activities by school supervisors, both originating from the supervisors themselves and factors outside of the supervisors.

As educational staff, teachers need the assistance of supervisors. Teachers are school personnel who are always faced with various things where they cannot solve the problem thoroughly without getting help from the supervisor. Siahaan said that the most difficult thing faced by teachers is facing changes in community demands, namely demands that are quite heavy from the community so that curriculum changes are needed.

The main essence of the supervisor's performance is not finding fault or cornering the teacher, but looking for conformity between the supervisor's plan and the implementation of work or it can also be said to seek the truth of the work carried out by the supervisor. Government Regulation No. 19 of 2005 concerning national education standards in article 39 paragraph (1) explains that supervision on formal education is carried out by education supervisors. Meanwhile, in Article 40 paragraph (1), non-formal education is carried out by the education unit inspector.

Optimal supervisor performance will determine success in achieving goals. For this reason, knowledge for supervisors is needed in order to make adjustments between work activities and the established plans. If there is a discrepancy between the implementation and the predetermined plan, action must be taken to correct and correct deviations or errors, so that the implementation of work does not experience more fatal and detrimental obstacles.

To achieve the goals of education often face challenges and obstacles, especially the most basic is the issue of human resources, especially regarding the quality of human resources. The supervisor's lack of knowledge about supervision can have work consequences that will be feared to tend to just look for mistakes. In educational institutions, supervisory activities should provide assistance and services to correct non-conformance with the plan through supervisory knowledge so that deviations do not occur.

The implementation of National Education as an integrated system between the central government and provincial and city district governments in Indonesia turns out to have many gaps in its implementation. One aspect that affects this national system is that each local government has a different concentration according to the vision and mission of each regional head. Both at the provincial and district/city levels.

This allows the concentration on the implementation of education in the regions to be very diverse. It is not impossible that the political aspect is the main reason for every regional head in organizing and developing development in the education sector in his region, both visible and hidden. The aspects of the regional head's goodwill and economic benefits have not yet been mentioned in the government environment or circles outside the government

In addition, there are often many problems in the accountability of the School Operational Assistance (BOS) and Special Allocation Funds (DAK) which are disbursed by the central government (the Ministry of Education and Culture) directly to schools. This competency is not owned by the principal because the principal's management is prioritized on the aspect of developing the quality of learning (curricular approach) and graduates/outputs, not the management of infrastructure development projects.

To follow up on this, the authors feel the need to conduct in-depth and comprehensive research on " The Role of Supervisors in the Implementation of the National Education System"

\section{RESEARCH METHODS}

Research is a systematic, directed and purposeful scientific activity. So, the data or information collected must be relevant to the problem at hand. This means that the data is related, relevant and accurate.(Kartini Kartono in Marzuki, 2006 )

A method is a way of working or working procedures to be able to understand the object that is the target of the science concerned. The method is a guide for how a scientist learns and understands the steps he faces (Soekanto and Mamudji, 2007) . 


\section{Research Type}

The definition of legal research according to Peter Mahmud Marzuki is a process to find the rule of law, legal principles, and legal doctrines in order to answer the legal issues faced.(Marzuki, 2006) Moving on from the definition, this type of research is normative juridical research. Normative juridical research is a legal research method that is carried out by examining library materials or mere secondary materials.(Soerjono Soekanto and Sri Mamudji, 2007)

\section{Source of Legal Material}

The source of legal materials in this study comes from library research, where library research uses primary legal materials, secondary legal materials and tertiary legal materials. Primary legal materials are materials whose contents are binding because they are issued by the government or institutions that have the authority. And secondary legal sources are materials in the form of books and other printed materials, as well as software, namely by accessing a number of data via the internet ( downloading) various books, scientific journals and research results, as well as tertiary legal materials. support primary legal materials and secondary legal materials (Sondakh, 2009).

\section{Legal Materials collection techniques}

In this study, the techniques of collecting legal materials used are primary legal materials and secondary legal materials. Research materials in the form of primary legal materials referred to in this study are laws related to research topics and problems. While secondary legal materials include materials that support primary legal materials such as textbooks, articles in various scientific magazines or research journals in the field of law, papers submitted in various forms of meetings such as discussions, seminars, workshops, and others. -other.

\section{Legal Material Analysis Techniques}

The analysis of legal materials used in the research is carried out in a qualitative and comprehensive analysis (Sondakh, 2009). Qualitative analysis is to describe quality legal materials in the form of regular, coherent, logical, and non-overlapping and effective sentences so as to facilitate the interpretation of legal materials and understanding of the results of the analysis, while comprehensive means that the analysis is carried out in depth and from various aspects according to with the scope of research.

The analysis of legal materials in this study was carried out using descriptive techniques, describing materials by constructing laws and arguments, which were then assessed based on legal reasoning reasons related to the problem.

\section{RESULTS AND DISCUSSION}

In order to optimize the implementation and quality control of education services in the regions, education supervision is one of the important series in the management process. The core of the discussion of educational supervision is mainly focused on achieving the quality and performance of education. Through monitoring activities, it is hoped that every educational plan can be carefully and carefully structured, every implementation of educational activities can run according to what has been planned, and at the end of the activity it can be seen how far the previously planned educational goals have been achieved. Meanwhile, in the perspective of national education policy, there are also several juridical foundations regarding the importance of educational supervision.

In Law no. 20 of 2003 concerning the National Education System, Article 66 mandates the importance of supervising the implementation of education at all levels and types of education, both by the government and the community. Supervision by the government comes in various forms, one of which is educational supervision carried out by school supervisors. According to the Decree of MENP AN no. 118 of 1996, school supervisors are functional officials in charge of carrying out guidance and assessment of the schools they foster, both at the personal and institutional levels. Furthermore, followed by Permendiknas No. 12 of 2007 concerning school supervisory standards which regulate the qualifications and competencies of school supervisors.

A supervisor must be able to carry out supervision that is not limited to routine, but prioritizes pedagogic values and quality in the educational process. Another challenge and obstacle for supervisors is related to capital to carry out supervisory activities. Ideally, this activity requires the addition of work equipment, facilities and communication.

A supervisor must know what and how supervision is. Both theoretically and in application in the field. Armed with that knowledge, a person can carry out his duties properly. Supervision knowledge includes mastering methods, techniques and principles of supervision, compiling supervision programs, compiling work methods and necessary instruments, compiling reports, fostering principals and teachers in education management based on quality improvement management and encouraging teachers and principals to reflect on the results. - the results achieved, monitoring the implementation of national education standards, guiding teachers in planning, implementing, managing media, selecting learning methods, and motivating teachers to use information technology in learning.

Theoretically and conceptually, it appears that supervision has a very strategic role in the implementation of the national education system at the central and regional levels. However, the conditions in the field are in stark contrast to what should be a common goal. 


\section{State Supervision of the Implementation of the National Education System}

\section{Education Supervisor}

Etymologically, the word supervision or supervision is a term which in English is supervision, consisting of two words, namely super and vision, which means to look carefully at the work as a whole. Meanwhile, the person who carries out these supervisory activities is known as the supervisor (supervisor).(RI Ministry of Religion, Education Supervision ,2005) Supervisor (supervisor) is one of the educational staff, whose task is to provide supervision so that educational staff (teachers, chancellors, deans, program heads, directors, principals and other personnel in schools) can carry out their duties properly.

Professional positions in the field of education as stated that there are personnel who carry out supervisory duties. In this case, supervision has a very broad meaning and people often state that supervision can also be interpreted as control, namely the process of comparing actual performance with standards and corrective actions that need to be taken.( Mukhtar ,2011)

Education supervisors ( supervisors ) are also educational leaders who influence the learning process through supervision and guidance of teachers. Even though the supervisor does not deal directly with students, the supervisor's behavior will certainly affect the teacher's behavior if the supervision is carried out with good management. Therefore, educational supervision is also developed as a profession for education personnel which is considered important within the framework of the national education system.

Supervisors are given the task, responsibility and full authority to carry out supervision by providing assessment and guidance from the technical aspect of education and administration in an education.( Mondy and Shane ,1995)

Supervision is one of the functions of management. This function absolutely must be done in every organization and institution.(Ibrahim Bafadal ,2005) In this way, the goals of the organization can be achieved as well as possible and in accordance with the plans that have been set previously.(Mukhtar ,2011) Supervision in the world of education is more popularly known in terms of supervision indicating the process, while supervisor or education supervisor refers to the person who supervises the education and learning process.

Supervision can be interpreted as a professional service. The professional service process is in the form of providing assistance to school personnel in improving their abilities so that they are better able to maintain and make changes to school administration in order to improve the achievement of school goals. Professional services can be in the form of helping teachers improve their abilities in managing the teaching and learning process in order to achieve school goals. Thus, educational supervision is essentially a series of activities to help school personnel improve their abilities.(Ibrahim Bafadal ,2004)

There are several opinions related to the notion of supervision (supervision) in the guidebook for the development of education administration and supervision, namely, Ben M. Haris in "Supervisor Behavior in Education ", (1975), stating that supervision is what school personnel do with adults. and tools in order to maintain or change school management to directly affect the achievement of school instructional goals. Supervision has an impact with students through the mediation of other people and tools. Neagley and Evans in "Handbook for effective supervision of Instruction ", (1964), stated that " supervisor is used to describe those activities which are primarily and directly concerned with studying and improving the conditions which surround the learning and growth of pupils and teachers . "(Ministry of Religion of the Republic of Indonesia ,2010)

William H. Burton explained that: "Supervison a social Process", stated that "supervisor is an expert technical service primarily at studying and improving cooperatively all factors which affect child growth and development."(Ministry of Religion of the Republic of Indonesia ,2010) Ametembun in "Educational Supervision", stated that educational supervision is guidance towards improving the educational situation in general and improving the quality of teaching and learning in the classroom in particular.(Ministry of Religion of the Republic of Indonesia ,2010) Meanwhile, according to Burhanuddin Harahap, in his book Supervision of Education, said that supervision is an activity carried out on people who cause or have the potential to cause twoway communication. Purwanto et al., stated that supervision is a coaching activity that is planned to assist teachers and other school staff in carrying out their work effectively.(Ministry of Religion of the Republic of Indonesia ,2010)

Based on the thoughts above, it can be said that educational supervision is an effort made to improve the quality of the educational process carried out in schools/madrasahs supported by optimizing the role of teachers, availability of facilities and infrastructure, curriculum design, learning systems and assessment and measurement mechanisms. Supervisors have the duty and responsibility to pay attention to the development of these elements on an ongoing basis. In the educational process, supervision or supervision is an integral part of efforts to improve learning achievement and school quality. Sahertian emphasized that the supervision or supervision of education is nothing but an effort to provide services to educational stakeholders, especially to teachers, both individually and in groups in an effort to improve the quality of learning processes and outcomes.(Sahertian ,2000)

Basically, supervision contains several main activities, namely continuous coaching, professional development of personnel capabilities, improvement of learning situations, with the ultimate goal of achieving educational goals and personal growth of students. In other words, in supervision there is a service process to help or develop teachers to be more professional. This coaching leads to an improvement or increase in the professional ability of teachers. The improvement and improvement of the teacher's ability is then transferred into teaching behavior so as to create a better learning situation, which in turn also increases the growth of students.

The analysis above is in line with the opinion that: the purpose of supervision should be the enhancement of teachers' pedagogical skills, with the ultimate goal of enhancing student avhievement".(Marzano ,2011) This means that the purpose of supervision is to improve the pedagogic ability of teachers, with the main objective being to improve student achievement.

The activity of the education supervisor in schools is to assess and foster the implementation of education in a number of educational units in certain public and private schools that are their responsibility. The assessment was carried out to determine the degree of quality based on the criteria (benchmarks) set for the implementation of education in schools. While coaching activities are carried out in the form of providing direction, advice and guidance. 
From the description above, it can be interpreted that supervision is an activity or supervisory action of a person who is given the task, responsibility and authority to carry out guidance and assessment of the person and or institution he fosters. A person who is given the task is called a supervisor or supervisor. In the field of education, it is called school supervisor or education unit supervisor. Supervision needs to be carried out with the aim of continuously improving the quality of education in the schools it supervises.

Indicators of improving the quality of education in schools are seen in each component of education, including: the quality of graduates, the quality of teachers, school principals, school staff (Administrative Staff, Laboratory Assistants and Technicians, Librarians), the learning process, facilities and infrastructure, school management, curriculum implementation, scoring system and other components. This means that through supervision, the impact on school performance must be seen in improving the quality of education. That is why the presence of school supervisors must be an integral part in improving the quality of education, so that together with teachers, principals and other school staff, they collaborate to foster and develop the quality of education in the school concerned as optimally as possible in accordance with the standards that have been set.

Supervision in education has been around for a long time, however, not everyone in the world of education knows what the nature of supervision is. Supervision means less realistic caused by:

1. Supervision is equated with controlling or supervising work, supervisors supervise more than experience ideas. Helping teachers improve their teaching methods is not a major concern, people tend to become restless and afraid when they are monitored or evaluated.

2. The interests and needs of supervision do not come from the teachers, but the supervisors themselves carry out their duties.

3. The supervisor himself may not know what he will be interested in and assess, while the teacher also does not have the knowledge of what the supervisor is interested in and assesses. As a result, the observational data is clearly unsystematic, highly subjective and unclear.

4. On the other hand, most teachers do not like supervision even though it is part of their education and work process.

The supervisor's role as an integral part in improving the quality of education in the school in question can be explained in the nature of supervision, as stated by Sudjana, et al (2006) It appears that the nature of supervision has four dimensions: (1) Support, (2) Trust, (3) Challenge, and (4) Networking and Collaboration. Each of the four dimensions of the nature of supervision is described below.

1) The first dimension of the nature of supervision is the Support dimension. This dimension refers to the nature of the supervisory activities carried out by the supervisor that must be able to support the school to self-evaluate its existing condition. Therefore, the supervisor and the school can analyze the strengths, weaknesses and potential and opportunities of the school to support the improvement and development of the quality of education in schools in the future.

2) The second dimension of the nature of supervision is the Trust dimension. This dimension refers to the nature of supervisory activities carried out by supervisors that must be able to build the trust of educational stakeholders by depicting a better and more promising future school dynamic profile.

3) The third dimension of the nature of supervision is the Challenge dimension. This dimension refers to the nature of the surveillance activities conducted by the supervisor must be able to challenge (challenge) the development of the school to stakeholders in school education. This challenge must be made as realistic as possible so that it can and can be achieved by the school, based on the current situation and condition of the school, thus stakeholders are challenged to work collaboratively in the context of developing school quality.

4) The fourth dimension of the nature of supervision is the Networking and Collaboration dimension. This dimension refers to the nature of supervisory activities carried out by supervisors that must be able to develop networks and collaborate among educational stakeholders in order to increase productivity, effectiveness and efficiency of education in schools.

The focus of the four dimensions of the nature of supervision is formulated in three main activities of supervision, namely: negotiation, collaboration and networking. Negotiations are carried out by supervisors with education stakeholders with a focus on what substances can and need to be developed or improved and how to improve them. Collaboration is the core of supervision activities that must always be held together with education stakeholders in the target schools. This is important because the estuary for improving the quality of education is on the school side. Networking is the essence of prospective supervision activities to be developed, especially in the era of globalization and cybernet technology as it is today.

The quality of supervisors based on the work done according to Leddick and Dye, is very comprehensive, namely: (Peter Hawkins and Robin Shohet ,2006)

1) Flexible; moving between theoretical concepts and a variety of methods;

2) A person who has many views is a person who is able to see the same situation from various angles;

3) Disciplined work planning with the person they are supervising;

4) Ability to work transculturally;

5) Capacity to organize and have a strong desire to provide supervision;

6) Openness to supervision and learning from important new situations;

7) Respond to emerging issues;

8) Can handle force appropriately;

9) Fun, humble and patient.

The existence of school/madrasah supervisors or educational unit supervisors are professional education personnel who are given full duties, responsibilities and authority by officials who are authorized to carry out coaching and supervision of education in schools, both supervision in the academic (technical education) and managerial (management) fields. school). 
The supervisory position is a functional position not a structural position so that to bear the title as an education supervisor, it must have the status of educators/teachers and or school principals/deputy principals. At least an education supervisor has been a teacher. In the supervision of subjects with the core of a supervisor mastering the teaching program supported by other elements, such as understanding the duties of the teacher, there is support for facilities and infrastructure, curriculum, learning systems and strategies and assessment.

Supervisors have the duty and responsibility to pay attention to the development of these elements on an ongoing basis. The supervisor's focus is on the development and progress of students, because of that their efforts, such as improving approaches, methods and techniques of teaching religion, curriculum development, using teaching aids/tools, improving assessment methods and procedures, creating conducive conditions in schools and so on. To help increase the insight and professional abilities of religious teachers, efforts are made by supervisors/supervisors, such as conducting school visits, class visits, individual and group coaching, setting examples of good teaching methods, encouraging increased collaboration, encouraging increased creativity and so on.

Seeing the importance of the role of supervisors/supervisors in improving the quality of education and teaching in schools, in this new era, supervisors have been appointed as fully functional officials whose consequences are that every supervisor must have professional insight and abilities beyond the professional abilities of teachers, principals and all school staff in education and administration. If not, then the existence of supervisors will not have any influence on the conditions of education and teaching in schools.

In fact, supervision has a broad meaning. Supervision is any assistance from school leaders and supervisors, which is aimed at developing the leadership of teachers and other school personnel in achieving educational goals. The supervision process carried out by the supervisor is an encouragement, guidance, and opportunity for the growth of the skills and abilities of teachers, such as guidance in business and implementation of reforms in education and teaching, the selection of teaching tools and better teaching methods, ways systematic assessment of the phases of the entire teaching process. Supervision is a coaching activity that is planned to assist teachers and other school staff in carrying out their work effectively.(Purwanto ,2009).

The supervisory process carried out by the supervisor is the last method taken in managerial activities, after planning, organizing and mobilizing. So supervision or controlling is the process of observing or monitoring organizational activities to ensure that all work goes according to plan to achieve good goals carried out by managers or functional staff who hold supervisory positions.

In order to realize the success of education and professional endeavors, visits by a supervisor/supervisor should be carried out regularly and continuously. In order for the implementation to run effectively and efficiently, several things need to be considered as steps, namely:

1) Programming

2) Preparation

3) Implementation

4) Follow-up supervision (Thaib BR ,2005)

A supervisor before making a work program, he must first understand the main tasks he will do as a form of responsibility. Supervision is of many types covering the entire educational process. Among these supervisions are supervision of the school's vision and mission, supervision of the bureaucracy, policies and the education system; learning supervision; clinical supervision; supervision of principal leadership, standard supervision of school principals, professional supervision of school professionalism, supervision of education financing, supervision of school productivity; effective school supervision, supervision of community empowerment in education, supervision of school administration; and supervision of the responsibility and accountability of school culture supervision.(Asmuni ,2012)

In accordance with SK MENPAN No. 118 of 1996 Chapter II Article 1 paragraph (1), regarding functional positions and credit numbers, the main task of school supervisors is civil servants who are given full duties, responsibilities and authority by officials who are authorized to carry out supervision in schools by conducting assessments and coaching in terms of technical education and administration in pre-school, primary and secondary education units.

According to the Minister of State Apparatus Empowerment and Bureaucratic Reform Regulation No. 21 of 2010 concerning Functional Positions of School Superintendents and their credit scores, the main task of supervisors is to carry out academic and managerial supervision in educational units which includes supervisors program compilers, implementation of coaching, monitoring of the implementation of 8 (eight) National Education Standards, Assessment, Guidance and Professional teacher training, evaluation of the results of the implementation of the supervision program in the Special Region.(Ministry of National Education ,2011)

What is meant by academic supervision is supervision relating to the following matters:(Ministry of National Education ,2011)

1) Planning teaching.

2) Carry out learning

3) Assessing learning outcomes

4) Guiding and training students

5) Carry out additional burdens attached to the implementation of the main activities in accordance with the workload.

These five things can be done face-to-face or non-face-to-face and it is also hoped that the role of an academic supervisor is

1) As a resource person.

2) As a facilitator 
3) As a motivator

4) As a teaching quality control tool

5) As an additional role if an academic supervisor is also an assessor in the context of school accreditation so that accreditation activities get accurate data.

(Hasan, et.al ,2002)

Meanwhile, managerial supervision is supervision related to aspects of school management that are directly related to improving school efficiency and effectiveness which includes planning, coordination, implementation, assessment, competency development of educators and educational staff. As a manager, a school supervisor plays a role:

1) Facilitator in the process of planning, coordinating, developing school management.

2) Assessors in identifying strengths and weaknesses and analyzing school potential.

According to Mulyasa, the criteria for effective supervision are:

1) Able to empower teachers to carry out the learning process well, smoothly and productively.

2) Can complete tasks and work within the specified time.

3) Able to establish harmonious relationships with the community so that they can actively involve them in realizing school and educational goals.

4) Successfully apply leadership principles in accordance with the maturity level of teachers and other employees in the school.

5) Work with the management team.

6) Successfully realize school goals productively in accordance with the provisions that have been set. (Mulyasa ,2004)

Of these six criteria, a supervisor must make an accurate work program so that the continuity of supervision has a positive impact. And a supervisor must be able to be innovative and creative in carrying out tasks, especially in compiling and applying programs in each stage of supervisory activities.

The thoughts mentioned above are in contrast to the reality on the ground, where the results of observations and document studies in the field prove that in the implementation of the national education system in the regions, especially in Maluku Province in relation to management supervision by education supervisors, it can be said to be stagnant or not working at all. This is evident from the absence of any monitoring reports as evidence he had done surveillance activities in the work unit / school by the superintendent of education in order to improve the quality of education in accordance with the basic philosophy and pri $\mathrm{n}$ sip the implementation of the national education system.

This condition is not something new now but has been happening in Maluku Province for a very long time. The phenomenon of infrastructure preparation in education units (schools) is that school principals can have the authority to hold infrastructure projects / school physical buildings so that it seems that school principals are busy taking care of projects and not taking care of the learning process and developing educators The principal is the status of a teacher who gets additional assignments, not the status of a regional official in the school environment. Therefore, the real authority to manage educational infrastructure at the education unit level must be within the authority of the regional apparatus organization of the education office or other related OPD such as the Public Works office.

This condition occurs because local government policies in the field of education across provinces, districts/cities always vary in terms of budgets, main tasks and functions (tupoksi) of Regional Apparatus Organizations (OPD). Across the OPDs, they still do not support each other and still seem to work independently, even though all OPD work is directed at the Vision-Mission of the regional head. This means that each OPD no longer formulates the OPD Vision-Mission but all adhere to the Regional Head's Vision-Mission which is then implemented into the OPD activity program. Therefore, synergy and collaboration across OPD are expected in order to provide quality National Education Standards to every student in the region.

\section{Education Supervision}

Supervision comes from the word supervisor which is stated in the Government Regulation of the Republic of Indonesia Number 38 of 1992 concerning Education Personnel as well as in the Law of the Republic of Indonesia Number 20 of 2003 concerning the National Education System, Article 1 paragraph (5) states that education personnel are members of the community who devote themselves and appointed to support the implementation of education.( Siahaan ,2006)

Meanwhile, in the Decree of the Minister of State for Empowerment of State Apparatus Number 118 of 1996 which was renewed by the Decree of the Minister of State for Empowerment of State Apparatus Number 091/KEP/MEN.PAN/10/2001 it was stated that school supervisors are civil servants who are given the task, responsibility and full authority by the authorized official to supervise education in preschool education units, primary schools, and secondary schools.(Siahaan ,2006)

To oversee the implementation of educational programs and processes, the government appoints special functional personnel called school supervisors, or supervisors. Explained by Hawkins and Shohet, that: the existence of a supervisor is to provide an opportunity to improve skills development in helping others and developing the work of teachers.(Hawkins and Shohet ,2006) That means, the task of supervising education is carried out by supervisors or supervisors to help develop teachers so that learning is effective and improves the quality of education, especially graduates produced by schools.

To achieve this goal, a supervisor is expected to be able to play a role:

a) As a resource for teachers in planning and carrying out their duties, as well as in diagnosing success, so that teachers can continuously improve their performance.

b) As a facilitator and even a mentor who helps teachers in overcoming the obstacles faced and in overcoming the shortcomings experienced.

c) As a motivator who in various ways always strives to want to work more seriously and enthusiastically. This includes providing pressure and support for teachers to achieve their teaching outcomes. 
d) As a teaching quality control apparatus (quality assurance auditor) who periodically and systematically checks, analyzes, evaluates and directs and takes action so that the three strategies in increasing the effectiveness of teaching above can be carried out properly and successfully.

e) As an additional role, the authors argue that it is appropriate if an academic supervisor is also an "assessor" for the interests of the school's accreditation program. Thus, accreditation activities can obtain accurate data regarding the teaching process because there are sources of information to confirm various things. (Hasan, et al ,2002)

Based on the opinion above, it can be concluded that supervision is defined as a process/monitoring activity to ensure that all organizational activities are carried out as previously planned and at the same time it is also an activity to correct and correct if deviations are found which are considered to be able to interfere with the achievement of goals. Supervision is also a management function needed to evaluate the performance of the organization or units within an organization in order to determine progress in the desired direction.

Indicators of an educational success or improving the quality of education in schools are seen in each component of education. Elements of education as a system that affects the quality of education consist of, among others: the quality of graduates ( output), the quality of teachers, principals, school staff (Administrative Staff, Laboratory Assistants and Technicians, Librarians), the learning process, facilities and infrastructure, school management, curriculum implementation, system assessment and other components. All of which go through the process of supervision, and the positive impact on school performance in improving the quality of education must be seen. That is why the presence of school supervisors must be an integral part in improving the quality of education, so that together with teachers, principals and other school staff, they can work together on an ongoing basis in an effort to foster and develop the quality of education in the school concerned as optimally as possible in accordance with the standards that have been set.

In the process of implementing education, supervision is an inseparable part of efforts to improve learning and teaching achievement and improve school quality, because educational supervision is nothing but an effort to provide services or assistance to educational stakeholders, especially to teachers, both individually and individually. in groups in an effort to improve the quality of learning processes and outcomes.

Assistance provided to teachers must be based on careful research or observation and an objective and in-depth assessment with reference to the learning program planning that has been made. The assistance process that is oriented towards efforts to improve the quality of the learning process and outcomes is important, so that the assistance provided is truly on target. So help is given it should be able to improve and develop teaching and learning situation towards a better. Because it, Need professional help for teachers to create a climate conducive learning in achieving the quality of education is expected.

The purpose of supervision of education and teaching is not only related to cognitive or psychomotor aspects, but also relates to affective aspects of the whole personality. The objectives of supervision consist of:

1) Improved quality of supervision. This activity can be done through direct visits when teachers teach in class, direct conversations with their peers or with some of their students.

2) Professional development. Where in this case the supervisor can assist teachers in understanding teaching, classroom life and developing teaching skills.

3) Increase the motivation of teachers to develop their own abilities and have serious attention to their duties and responsibilities. (Siahaan, et al ,2006)

In addition, supervision (or in other terms often called supervision) carried out in education must meet the principles of supervision which include:( Siahaan, et al 2006)

1) First, teaching supervision must be able to create harmonious human relations.

2) Second, teaching supervision must be carried out continuously.

3) Third, teaching supervision must be democratic.

4) Fourth, the teaching supervision program must be integral to the education program.

5) Fifth, teaching supervision must be comprehensive (covering all aspects of teaching development).

6) Sixth, teaching supervision must be constructive.

7) Seventh, teaching supervision must be objective.

From the various explanations described above, all of them provide a clearer picture that between education management which seeks to obtain maximum results will not be separated from a supervisory process carried out by an education supervisor. In other words, education management and education supervisors are inseparable parts in order to achieve educational goals.

For this reason, staff in serving children of students in any type of education requires reliable and professional personnel in carrying out supervisory activities. Because not a few are found in the field, that quantitatively there are adequate supervisory personnel available, but qualitatively the condition and performance of the workforce still does not meet the minimum competency criteria. Therefore, it is necessary to continue to pursue the development of a coaching program

In relation to the supervision of the national education system in the regions, the author can argue that the implementation of National Education as an integrated system between the central government and the provincial and district-city governments in Indonesia turns out to have many gaps in its implementation. One aspect that affects this national system is that each local government has a different concentration according to the vision and mission of each regional head. Both at the provincial and district/city levels. This allows the concentration on the implementation of education in the regions to be very diverse. It is not impossible that the political aspect is the main reason for every regional head in organizing and developing development in the education sector in his region, both visible and hidden. Not to mention the aspects of the goodwill of regional heads and economic benefits within the government and outside government circles. 
Provinces have the authority to set education policies at the high school level (SMA/SMK/MA), while on the other hand, district/city governments have the authority to administer education at the elementary and junior high school levels. In the aspect of the relationship between the Province and the regencies/cities, it is often out of sync in the vision and mission, especially in planning, implementing work programs and policies in the education sector.

The visions and missions of the regional head usually produce the Regional Medium Term Development Plan (RPJMD) and then produce the Activity Program designed by the Education Office and accompanied by the regional head's policy in the practice of implementing education in the region. This actually requires a head of the education office who has the skills, creativity and innovation in the field of education to formulate a coherent concept as an integrated system through activity programs at the district/city level with the province and the center. If this can be implemented, the actual supervision of the implementation of the national education system will be more systematic to achieve common goals or national ideals.

The formulation of educational activity program planning by each education office in each district/city refers to the RPJMD which has implications for the available budget allocation. Because of that, actually a head of service as a technical Regional Apparatus Organization (OPD) plays a very important role in innovating and elaborating central and regional programs, so that they do not only surrender or depend on limited regional budgets but can optimize the use of the central budget to implement the synergy of central and regional programs. In this aspect alone, it often does not work well, because the condition of human resources in the Regional Office is still limited and regional interests are often not in line with the interests of the center.

Almost all districts/cities in Maluku Province do not have Regional Regulations and/or Regent/Mayor Regulations that specifically regulate the education system in the regions that can run consistently and continuously during the term of government in a sustainable manner. Its implementation is more directed to the vision and mission of the regional head which in its implementation is often influenced by policies due to certain interests. Not to mention the synchronization of the education system between Teacher Universities and the Regional Government in Maluku according to regional and socio-cultural conditions. This certainly affects the supervision of the implementation of the education system in a holistic manner.

Another fact is that the implementation of the education system in Maluku is still running partially on the basis of regional sectoral egos (each district/city) and has not been able to become a complete shared commitment to the Maluku Province's big vision regarding the development of the education sector. Therefore, the education sector in Maluku must be integrated with other sectors as a Pentahelix synergy, namely the collaboration of 5 (five) subject elements or regional development-oriented stakeholders, namely Academics, Business, Community, Government and Media.

\section{CONCLUSION}

State supervision of the implementation of the National Education System in this paper includes education supervisors and education supervision. Supervisor ( supervisor ) is one of the educational staff, whose task is to provide supervision so that educational staff (teachers and other personnel at school) can carry out their duties properly. While supervision is a process of leadership, management, structuring, monitoring, application of regulations, cooperation between school personnel which is intended to achieve educational goals in a comprehensive, systematic, effective and efficient manner. However, the reality on the ground proves that the supervisory function in the context of implementing the education system in the regions, especially in Maluku Province, has stagnated or does not work at all in accordance with the principles of implementing a national education system based on Pancasila, the 1945 Constitution of the Republic of Indonesia and the National Education System Law.

\section{REFERENCES}

1. Asmuni, Jamal Ma'ruf 2012 Effective Tips for Supervision of School Education (Jogjakarta: DIVA Press, 2012), p. 82. [In Indonesia]

2. Bafadal Ibrahim,2004., Fundamentals of Kindergarten Management and Supervision (Jakarta: Bumi Aksara, 2004$)$, p.72. [In Indonesia]

3. Bafadal, Ibrahim , 2005. Primary School Quality Improvement Management (Bandung: Bumi Aksara, 2005), p. 46. [In Indonesia]

4. Hasan, Yusuf A. et al,2002. Supervision Guidelines for Madrasahs and Public Schools ( Jakarta: Mekar Jaya, 2002 ), p. 6. [In Indonesia]

5. Hawkins Peter and Shohet Robin,2006. Supervision in the Helping Professions (New Jersey: Open UniversityPress, 2006), p.50. 
6. Marzano Robert J, Frontier Ony, Livingston David,2011., Effective Supervision (Alexandra Virginia, 2011), p.2.

7. Marzuki, Peter Mahmu, 2006, Legal Research, cet.2, Kencana Prenada Media Group, Jakarta, p.35[In Indonesia]

8. Marzuki, Research Methodology, 1st edition, UII Press, Yogyakarta, p.55 [In Indonesia]

9. Ministry of National Education 2011, School Supervisor Workbook (Jakarta: Education Personnel Development Center, PSDM and PMP Agency, 2nd Cet., 2011), p. 10. [In Indonesia]

10. Ministry of Religion of the Republic of Indonesia, 2010. Improved Supervision and Evaluation of Madrasah Ibtidaiyah (Jakarta: Director General of Islamic Institutions, Directorate of Madrasah and Islamic Education in public schools, 2010), p. 8. [In Indonesia]

11. Ministry of Religion of the Republic of Indonesia, Education Supervision (Jakarta: Director General of Islamic Religious Institutions, 2005), p. 2. [In Indonesia]

12. Mondy, R. Wayne and Shane R, 1995. Premeaux, Management Concepts, Practices and Skills (New Jersey: Prentice Hall, 1995), p.512.

13. Mukhtar, Mukhneri, 2011 Supervision: Improving Performance and Development Quality in Education Jakarta: PPS UNJ, 2011, p.4. [In Indonesia]

14. Mulyasa E.,2004. School-Based Management (Bandung: PT. Teen Rosdakarya, Cet. 7, 2004), p.126.

15. Purwanto Ngalim,2009. Education Administration and Supervision (Bandung: PT. Teen Rosdakarya, 2009) cet. 19, p. 76. [In Indonesia]

16. Sahertian, Piet A. Basic Concepts \& Techniques of Educational Supervision (Jakarta: Rineka Cipta, 2000), p. 19. [In Indonesia]

17. Siahaan A, et al, 2006. Management of Education Supervisors (Ciputat: Quantum Teaching, 2006), p.1.

18. Soekanto Soerjono and Mamudji Sri, 2007, Normative Legal Research A Brief Overview, Raja Grafindo Persada, Jakarta, p.6 [In Indonesia]

19. Sondakh Devi K. G 2009, Individual Criminal Responsibility for Perpetrators of Violations of Human Rights in the Context of National Law Reform, Dissertation, Graduate Program, Hasanuddin University, Makassar. p. 240. [In Indonesia]

20. Sudjana Nana, et al,2006. Supervisory Quality Standards (Jakarta: Ministry of National Education, 2006), p.15. [In Indonesia]

21. Sudjana, Nana. 2009. Assessment of Teaching and Learning Outcomes . Bandung : PT. Rosdakarya Youth. hlm. 34 [In Indonesia]

22. Sukardjo and Komarudin Ukim, 2013, Educational Foundations of Concepts and Applications, Rajawali Prees, Jakarta, p. 15 [In Indonesia]

23. Thaib BR M. Amin 2005. , Educational Supervision and Evaluation Standards (Jakarta: DITMAPENDA, 2005 ), p. 103 115. [In Indonesia]

\section{AUTHOR}

First author $\quad$ : Henry M. Sopacua, Graduate Student PhD, Study Program: Science Of Law. Pattimura University, Ambon, Indonesia : Email : henrysopacua1 @ gmail.com

The second author : SEM Nirahua: Faculty Of Law. Pattimura University, Ambon, Indonesia 